\title{
KAIDAH PELESAPAN DALAM KONSTRUKSI KALIMAT MAJEMUK BAHASA INDONESIA
}

\author{
Teguh Setiawan \\ FBS Universitas Negeri Yogyakarta
}

\begin{abstract}
This research study aims to describe the rules of ellipsis in compound and complex sentences. The sources of the data were two newspapers, Kompas and Kedaulatan Rakyat, the edition of March 2002. The data were collected by using observation and recording techniques. They were then analyzed by the substitution method. On the basis of this method, the omission and substitution techniques were employed.

Based on the analysis of the findings, the subject, predicate and object ellipsis can be found in compound sentences and the subject ellipsis in complex sentences. The rules of ellipsis in compound sentences are that (1) the omission can be done if the omitted element is the same; (2) the omission of the subject and predicate is always made in the clause after the coordinative conjunction and the omission of the object is made in the clause before the coordinative conjunction; (3) the referential characteristic of the omitted element is always anaphoric. The rules of ellipsis in complex sentences are that (1) the omitted element must be the same; (2) the omitted element is in the clause preceded by a subordinative conjunction or the dependent clause; (3) the referential characteristic of the omitted element is cataphoric or anaphoric.
\end{abstract}

\section{A. Pendahuluan}

Penggabungan dua klausa, baik secara subordinatif maupun koordinatif dapat mengakibatkan terdapatnya dua unsur yang sama dalam satu kalimat. Penggulangan unsur yang sama akan mengakibatkan redudansi dari segi informasinya. Salah satu cara untuk menghindari atau untuk mengurangi redunansi itu adalah pelesapan atau elipsis. Pelesapan merupakan peniadaan unsur tertentu dalam suatu kalimat atau teks (Kridalaksana, 1985), misalnya, dalam kalimat Sebelum tidur, dia minum obat. Kalimat tersebut terdiri atas dua klausa, yaitu klausa terikat tidur yang diawali oleh konjungsi sebelum dan klausa bebas dia minum obat. Berdasarkan struktur kalimat tersebut, ada pelesapan subjek pada klausa terikatnya. Subjek yang dilesapkan itu mengacu secara kataforis pada pronomina dia yang ada pada klausa bebas. Dengan demikian unsur yang dilesapkan adalah pronomina persona dia. Pelesapan tersebut tidak hanya dapat dipulihkan kembali, tetapi juga tidak menyebabkan perubahan makna.

Sebagaimana dikemukakan di atas bahwa pelesapan juga terdapat dalam kalimat majemuk yang bersifat koordinatif. Contohnya, Anita telah menyapu dan mengepel lantai ini. Kalimat tersebut juga terdiri atas dua klausa yang dihubungkan dengan konjungsi dan. Berdasarkan struktur kalimatnya dapat diketahui bahwa pada klausa pertama terjadi pelesapan objek, yaitu lantai ini, sedangkan dalam klausa kedua terjadi pelesapan subjek, yaitu Anita. 
Pelesapan tidak selamanya dapat dengan mudah diketahui, ada kalanya untuk menentukan ada tidaknya pelesapan dalam suatu konstruksi majemuk menjadi permasalahan. Sebagai contoh, dalam konstruksi kalimat majemuk Saya dan ibu pergi ke pasar bila beranalogi dengan kalimat sebelumnya, kalimat tersebut harus dipandang berasal dari dua klausa yang salah satu klausanya mengalami pelesapan predikat (pergi) dan keterangan (ke pasar). Dengan demikian kalimat tersebut terdiri atas klausa saya pergi kepasar dan ibu pergi ke pasar. Dengan suatu alasan tertentu konstruksi kalimat majemuk tersebut dapat dianggap terjadi pelesapan. Akan tetapi bagaimana dengan kalimat Bendera Indonesia berwarna merah dan putih? Apakah dengan adanya kata tugas dan yang merangkai kata merah dan putih kita akan beranggapan bahwa kalimat tersebut terdiri atas dua klausa yang dalam salah satu klausanya terjadi pelesapan sebagaimana terjadi pada kalimat sebelumnya? Ataukah kalimat tersebut merupakan kalimat tunggal yang terdiri atas satu klausa? Demikian juga dalam kalimat Wati membeli buku dan tas. Apakah dalam kalimat tersebut ada pelesapan atau tidak? Berbagai permasalahan tersebut harus mendapat penjelasan yang akurat. Berdasarkan hal itu ada dua permasalahan inti yang perlu diungkap dan dijelaskan, yaitu bagaimanakah kaidah pelesapan dalam konstruksi kalimat majemuk koordinatif dan bagimanakan kaidah pelesapan dalam konstruksi kalimat majemuk subordinatif? Berdasarkan dua permasalahan di atas, penelitian ini bertujuan untuk mendeskripsikan dan menjelaskan kaidah pelesapan dalam konstruksi koordinatif dan kaidah pelesapan dalam konstruksi subordinatif.

Hasil penelitian ini memiliki manfaat teoritis dan praktis. Secara teoretis hasil penelitian ini dapat digunakan se- bagai salah satu penjelas pelesapan yang dalam beberapa buku, khususnya buku sintaksis belum banyak dikupas. Secara praktis hasil penelitian ini dapat dijadikan dasar oleh mahasiswa khususnya mahasiswa program studi bahasa Indonesia untuk menentukan ada tidaknya pelesapan dalam konstruksi kalimat majemuk koordinatif dan subordinatif.

\section{B. Metode Penelitian}

Sumber data penelitian ini adalah ragam bahasa tulis karena ragam bahasa tulis lebih eksplisit sifatnya. Adapun sumber data penelitian ini ditetapkan Kompas dan Kedaulatan Rakyat yang terbit mulai tanggal 1 Maret hingga tanggal 30 Maret 2003, yang difokuskan pada kolom berita.

Data penelitian ini berupa kalimat majemuk yang di dalamnya mengandung pelesapan. Data penelitian didapatkan dengan teknik baca-catat terhadap bentuk-bentuk pelesapan dalam sumber data. Selanjutnya, data yang telah diperoleh melalui teknik tersebut diidentifikasi dan diklasifikasi sesuai dengan bentuk dan maknanya.

Data yang terkumpul dianalisis dengan menggunakan metode distribusional, sedangkan metode agih digunakan untuk mengetahui kesesuaian unsur yang dilesapkan. Metode padan digunakan untuk mengetahui makna kalimat sebelum dan sesudah terjadinya pelesapan.

\section{Kajian Teori \\ 1. Pelesapan}

Istilah pelesapan seringkali digunakan untuk mengacu dua konsep, yaitu elipsis dan delisi. Pelesapan yang mengacu pada elipsis dimaksudkan sebagai peniadaan kata atau satuan lain yang wujud asalnya dapat diramalkan dari konteks bahasa atau konteks luar bahasa (Kridalaksana, 1985:45), sedang- 
kan proses peniadaan satu atau lebih elemen dari sebuah konstruksi disebut delisi. Dalam penelitian ini istilah pelesapan digunakan untuk mengacu konsep elipsis. Berdasarkan konsep elipsis yang dikemukakan oleh Kridalaksana, dapat dinyatakan bahwa peniadaan suatu bentuk bahasa baru dapat dilakukan bila didukung oleh konteksnya, baik konteks bahasa atau luar bahasa. Pendapat itu sejalan dengan pendapat Matthews (1997:111) bahwa elipsis merupakan penghilangan satu atau lebih elemen bahasa dari suatu konstruksi, penghilangan itu didukung oleh suatu konteks. Contoh :

(1) Kami akan mengambil barang bukti dan $\varnothing$ menyerahkannya kepada pihak kepolisian.

(2) Silakan Ø dimakan!

Bentuk yang dilesapkan pada kalimat pertama dapat diketahui berdasarkan konteks bahasanya, yaitu fungsi kami yang berfungsi sebagai subjek kalimat, sedangkan dalam kalimat kedua apa yang dimakan tidaklah dapat diketahui tanpa melihat situasi tutur, mungkin saja yang dimakan adalah nasi, roti, bubur.

Secara teoretis unsur yang dilesapkan dapat berupa unsur yang berfungsi sebagai subjek, predikat, dan objek. (Alwi, et al 1998) (Quirk, 1985), (Ramlan, 1987). Dalam kalimat (1) terjadi pelesapan subjek pada klausa sesudah konjungtor dan. Secara anaforis unsur yang dilesapkan itu mengacu pada bentuk kami. Contoh pelesapan predikat dan objek adalah sebagai berikut.

(3) Kami tidak tahu dia akan datang atau tidak $\varnothing$.

(4) Kepolisian telah memproses $\varnothing$ dan menyerahkan kasus itu kepada kejaksaan.

Pada kalimat (3) terdapat pelesapan predikat pada klausa sesudah konjung- tor atau, sedangkan pada kalimat (4) terdapat pelesapan objek pada klausa sebelum konjungtor.

\section{Kriteria Pelesapan}

Pelesapan pada dasarnya mengasumsikan ada bentuk yang sama dan salah satu bentuknya ditiadakan. Bentuk yang ditiadakan itu dengan dasar tertentu dapat dipulihkan kembali. Menurur Quirk et al (1985) dan Alwi et al (1998) ada dua kreteria suatu kontruksi dianggap terjadi pelesapan.

1. Kata yang dilesapkan secara persis dapat dipulihkan.

Bentuk-bentuk yang dilesapkan ada yang dengan mudah dapat diketahui secara pasti dan dapat dipulihkan kembali dengan tepat pula. Contoh :

(5) Saya ingin pergi ke tanah suci tetapi $\varnothing$ belum mempunyai uang.

Dalam kalimat di atas bentuk yang dilesapkan dapat secara tepat diketahui dan dipulihkan, yaitu saya.

2. Penyisipan kata sebagai bentuk pemulihan akan menghasilkan kalimat yang gramatikal dengan makna yang sama dengan kalimat aslinya. Contoh:

(6) Para pendemo memprotes kebijakan wali kota dan meminta wali kota mundur dari jabatannya.

(7) Warna baju Tim Indonesia adalah merah putih

Kalimat (6) merupakan kalimat majemuk setara. Dalam kalimat tersebut terdapat pelesapan subjek. Bila subjek yang dilesapkan ditulis lengkap menjadi Para pendemo memprotes kebijakan wali kota, dan para pendemo meminta wali kota mundur dari jabatannya. Hasil pemulihan itu tidak mengubah makna kalimat aslinya. Hal itu berbeda dengan kalimat 
(7), dalam kalimat itu walaupun ada kata dan sebagai kata yang menghubungkan dua kata merah dan putih tidak berarti bahwa kalimat itu merupakan kalimat majemuk. Hal itu didasarkan atas makna yang dihasilkan dari pemulihan seperti tampak di bawah ini.

(7a) Warna baju Tim Indonesia adalah merah putih.

(7b) Warna baju Tim Indonesia adalah merah dan warna baju Tim Indonesia adalah putih.

Hasil pembandingan dua kalimat tersebut memperlihatkan perbedaan makna antara kalimat (7a) dan kalimat (7b) berbeda.

\section{Tipe Keterpulihan}

Menurut Quirk et al (1985) suatu bentuk yang ditiadakan akan dapat dipulihkan (recoverability) berdasarkan tiga tipe, yaitu tipe tekstual, struktural, dan situasional. Tipe keterpulihan tekstual adalah kondisi yang memungkinkan penelusuran unsur yang dilesapkan berdasarkan teks. Tipe keterpulihan struktural adalah kondisi yang memungkinkan penelusuran untur yang dilesapkan berdasarkan struktur kalimat. Hal itu dapat dilakukan berdasarkan pengetahuan kita tentang struktur bahasa tertentu. Keterpulihan situasional adalah kondisi yang memungkinkan penelusuran unsur yang dilesapkan berdasarkan situasi. Bentuk yang dilesapkan dapat ditemukan pada situasi di luar bahasa. Contoh:

(8) Setiap pagi Ani menyapu atau mengepel lantai.

(9) Ambilkan buku itu!

(10) Silakan diminum !

Pelesapan subjek pada kalimat (8) dapat dipulihkan secara tekstual, yaitu mengacu secara anaforis pada bentuk Ani. Pada kalimat (9) bentuk yang dilesapkan adalah persona kedua kamu. Hal itu dapat diketahui berdasarkan pengetahuan struktur bahasa Indonesia. Keterpulihan pelesapan kalimat (10) merupakan contoh keterpulihan situasional, artinya bentuk yang dilesapkan dalam hal ini apa yang diminum hanya dapat diketahui berdasarkan situasi tutur, mungkin yang dilesapkan itu berupa teh, kopi atau susu.

\section{Tipe Pelesapan}

Berdasarkan posisi unsur yang dilesapkan, Quirk et al. (1985) membagi dua tipe pelesapan, yaitu pelesapan awal dan pelesapan final akhir. Contoh:

(11) I am happy if you are $\varnothing$.

(12) Agus datang ke pesta itu, tetapi saya tidak $\varnothing$.

(13) Karena $\varnothing$ sakit, dia tidak datang.

Kalimat (11) dan (12) merupakan contoh pelesapan akhir karena fungsi unsur yang dilesapkan berada diakhir suatu konstruksi. Konstruksi yang dicetak miring adalah unsur yang dilesapkan. Sebaliknya, kalimat (13) merupakan contoh pelesapan awal karena fungsi unsur yang dilesapkan berada di awal suatu konstruksi, yaitu pronominal ketiga dia.

\section{Konstruksi Koordinatif dan Subor- dinatif}

Pengabungan dua klausa baik secara subordinatif maupun secara koordinatif dapat mengakibatkan terdapatnya dua unsur yang sama dalam satu kalimat. Dilihat dari sisi efektivitas infomasi, pengulangan unsur yang sama itu tidak efektif. Pelesapan merupakan salah satu teknik yang dapat digunakan untuk menghindari hal itu. Dengan kata lain bahwa pelesapan dapat terjadi pada konstruksi subordinatif dan koordinatif. 
Secara semantis hubungan struktur subordinatif adalah struktur yang salah satu klausanya memiliki informasi penting dibandingkan informasi yang ada di klausa lainnya dan klausa yang digabungkan memiliki hubungan yang tidak setara (Sugono, 1985); (Sophen, 1996). Salah satu diantara klausanya merupakan klausa bebas dan klausa lainnya merupakan klausa terikat. Secara sintaksis dalam hubungan subordinatif salah satu klausanya merupakan bagian dari kalusa yang lain. Secara umum posisi klausa yang diawali oleh subordinator dapat berubah. Hubungan subordinator memungkinkan adanya hubungan kataforis. Contoh:

(14) Setelah $\varnothing$ lulus SMA, Nani ingin meneruskan ke PT.

Kalimat (14) terdiri atas dua klausa, yaitu (setelah) lulus SMA sebagai klausa terikat dan dia ingin meneruskan ke PT sebagai klausa bebas. Informasi yang ada pada klausa terikat dianggap kurang penting dibandingkan dengan informasi yang ada pada klausa bebas. Bila dilihat dari aspek pelesapkan, Unsur yang dilesapkan berada pada klausa terikat dan secara kataforis mengacu pada nama diri Ani. Sifat pengacuan unsur yang dilesapkan itu dapat pula menjadi anaforis bila posisi klausanya dibalik menjadi Nani ingin meneruskan ke PT setelah Ø lulus SMA.

Dalam kalimat itu unsur yang dilesapkan mengacu secara anaforis pada anteseden yang mendahuluinya atau di depannya.

Bila dalam konstruksi subordinatif salah satu klausanya merupakan bagian dari klausa lainnya atau tidak setara, dalam konstruksi koordinatif bersifat sebaliknya. Secara semantis dalam konstruksi koordinatif hubungan antarklausa setara, tidak ada klausa yang dianggap lebih penting. Adapun ciri sintaksis hubungan koordinatif adalah menghubungkan dua klausa dengan konjungtor koordinatif. Pada umumnya klausa yang diawali oleh konjungtor tidak dapat diubah. Dalam konstruksi koordinatif acuannya bersifat anaforis, sedangkan kataforis tidak diperoleh dalam hubungan koordinatif. Contoh :

(15) Kita akan meminjam atau membeli buku itu.

(16) Pemerintah menyiapkan dana untuk penanggulangan kemiskinan dan akan mengatur teknik penyalurannya

Kalimat (15) dan (16) masing-masing teridiri atas dua klausa dan kedua klausa tersebut memiliki hubungan yang setara. Pada kalimat (15) terdiri atas klausa kita akan meminjam dan membeli buku itu, sedangkan dalam kalimat (16) terdiri atas klausa pemerintah menyiapkan dana untuk penaggulangan kemiskinan dan akan mengatur teknik penyalurannya. Dari kedua kalimat itu tampak bahwa klausa yang sesudah konjungtor koordinatif atau, dan terdapat unsur yang dilesapkan. Unsur tersebut secara mengacu secara anaforif pada anteseden yang berada di depannya. Sifat acuan itu tidak dapat diubah menjadi kataforis seperti dalam konstruksi subordinatif. Hal itu terkait dengan ciri sintaksisnya bahwa posisi klausa dalam konstruksi koordinatif tidak dapat balik. Bila dibalik akan menghasilkan konstruksi yang tidak gramatikal seperti di bawah ini.

*(15a) Atau membeli buku itu kita akan meminjam

*(16a) Dan akan mengatur teknik penyalurannya pemerintah menyiapkan untuk penanggulangan kemiskinan 
D. Pembahasan

1. Pelesapan dalam Konstruksi Koor-
dinatif

a. Pelesapan Subjek

Pelesapan subjek merupakan gejala gramatikal yang berupa peniadaan unsur pengisi subjek pada suatu konstruksi bahasa. Seperti tampak pada kalimat berikut ini:

(1) Ia sudah bisa menerima dan $\varnothing$ tidak perlu lagi besembunyi (Kps, 14)

(2) Ia harus bekerja dan $\varnothing$ mencari uang sendiri (Kps, 16)

(3) Mereka tidak dibrogol dan $\varnothing$ dapat makan enak. (KR, 12)

(4) Dana solidaritas itu akan dikumpulkan oleh Dewan Masjid Indonesia (DMI) propinsi DIY dan $\varnothing$ akan disalurkan kepada rakyat Irak $(K R, 20)$

Kalimat (1-4) di atas merupakan kalimat majemuk yang klausaklausanya memiliki hubungan setara. Kesetaraan itu itu ditujukkan dengan hadimya konjungsi dan yang menghubungkan kedua klausa tersebut. Dalam keempat kalimat tersebut, tidak semua fungsi klausa hadir secara lengkap. Klausa sebelum konjungsi, yaitu ia sudah bisa menerima, ia harus bekerja, mereka tidak dibrogol, Dana solidaritas itu akan dikumpulkan oleh Dewan Masjid Indonesia (DMI) propinsi DIY merupakan klausa yang secara sintaksis mempunyai fungsi yang lengkap. Sebaliknya klausa sesudah konjungsi dan merupakan klausa tak lengkap. Ketidaklengkapan itu disebabkan ada salah satu unsur yang berfungsi sebagai subjek dilesapkan. Secara kontekstual, unsur yang dilesapkan itu mengacu secara anaforis pada subjek klausa sebelumnya, yaitu ia pada kalimat (1-2), mereka (3), dan dana solidaritas itu (4). Namun, tidak semua kalimat yang menggunakan kata dan dapat diprediksikan terjadi pelesapan seperti pada data berikut.

(5) MUIDIY mengutuk keras agresi Amerika dan sekutunya ke Irak (KR, 14)

(6) Kali ini Saddam tampil dengan memakai kemeja, jas dan pantalon warna tua (Kps, 17).

Kalimat 5 dan 6 tidak dapat dikatakan sebagai kalimat majemuk yang di dalamnya terdapat unsur yang dilesapkan. Bentuk Amerika dan sekutunya (5) kemeja, tas, dan pantalon wama tua (6). Kalimat itu tidak dapat dijabarkan menjadi seperti berikut ini

(5a) MUI DIY mengutuk keras agresi Amerika dan MUI DIY mengutuk keras agresi sekutunya ke Irak

(6a) Kali ini Saddam tampil dengan memakai kemeja, Kali ini Saddam tampil dengan memakai jas dan Kali ini Saddam tampil dengan memakai pantalon warna tua.

Secara semantis, kedua kalimat di atas tidak memiliki makna yang sama dengan kalimat aslinya. Padahal salah satu syarat dari pelesapan adalah makna kalimat sebelum dan sesudah dipulihkan tidak berubah. Penggunaan bentuk dan pada kedua kalimat tersebut harap dipandang sebagai bentuk rincian. Sebagaimana dikemukakan oleh (Quirk et al. 1985) bahwa nomina yang dijajarkan dengan konjungsi dan perubahannya hanya dari sisi tunggal ke jamak, tetapi tidak berimplikasi kepada pelesapan. Kedua kalimat di atas sama dengan kalimat berikut ini.

(7) Pada hari senin siswa sekolah dasar memakai seragam merah dan putih.

Kalimat itu tidak dianggap sebagai kalimat majemuk yang memiliki dua 
klausa, bandingkan maknanya dengan kalimat asal bila kalimat tersebut diuraikan menjadi berikut ini.

(7a) Pada hari senin siswa sekolah dasar memakai seragam merah dan pada hari senin siswa sekolah dasar memakai seragam putih.

Contoh pelesapan pada kalimat (1-4) di atas menunjukkan adanya kesamaan unsur pengisi subjek pada kedua klausanya. Dari data itu pula dapat dikatakan bahwa subjek yang dapat dilesapkan adalah yang berada sesudah konjungsi. Kedua, subjek dapat dilesapkan bila unsur pengisi subjek itu sama, bila tidak pelesapan tidak akan berterima. Contoh :

(8) Anak itu memang menangkap ayam saya, tetapi dilepaskan lagi. (KR, 11)

Kalimat itu memang merupakan kalimat majemuk koordinatif yang terdiri atas dua klausa, dan kedua klausa itu memiliki hubungan setara. Hal yang membedakan adalah unsur pengisi subjek pada kedua klausa berbeda. Subjek pada klausa pertama adalah anak itu, sedangkan pada klausa kedua subjeknya adalah ayam itu. Namun, subjek tersebut dilesapkan. Dengan berpedoman pada pemyataan di atas bahwa subjek yang dilesapkan harus sama dengan subjek pada klausa sebelumnya, pelesapan seperti itu tidak diperbolehkan. Unsur yang dilesapkan pada klausa kedua sama sekali tidak mengacu pada subjek klausa pertama, yaitu anak itu. Kalimat itu baru akan berterima pelesapannya bila diubah menjadi.

(8a) Ayam saya memang ditangkap oleh anak itu, tetapi dilepaskan lagi

Unsur yang dilesapkan pada kalimat itu setara jelasa dapat diketahui, yaitu ayam saya, yang juga merupakan subjek pada kedua klausa tersebut. Bentuk pelesapan dalam kalimat majemuk setara lainnya adalah sebagai berikut.

(9) Kedua pilotnya dikatakan selamat, tetapi $\varnothing$ hingga ini belum ditemukan (KR, 17)

(10) Mereka tidak saja mengabaikan Saddam, $\varnothing$ tetapi juga mengabaikan rakyat di dunia. (KR, 23)

Kalimat (9-10) merupakan kalimat mejemuk setara yang kedua klausanya dihubungkan dengan konjungsi tetapi. Kedua kalimat itu merupakan kalimat yang hubungan klausa-klausanya menyatakan makna pertentangan, yang ditunjukkan dengan konjungsi tetapi. Kesamaan lainnya adalah unsur yang dilesapkan berada pada klausa setelah konjungsi tetapi. Unsur yang dilesapkan adalah unsur yang berfungsi sebagai subjek. Secara anaforis unsur itu mengacu fungsi subjek dalam klausa yang mendahuluinya atau klausa sebelum konkungtor tetapi, yaitu kedua pilotnya dan mereka.

Kondisi yang memungkinkan adanya pelesapan subjek pada keempat kalimat tersebut sama dengan kalimat (1-4), yaitu unsur yang dilesapkan akan selalu berada pada klausa setelah konjungsi. Subjek yang dilesapkan harus sama dengan subjek pada klausa yang mendahuluinya. Ketiga unsur yang dilesapkan acuannya selalu bersifat anaforis. Bukti bahwa selalu anaforis adalah ketidakberterimaan pembalikan konstruksi koordinatif. Dalam bahasa Indonesia tidak akan berterima konstruksi yang demikian.

* Dan $\varnothing$ mencari uang sendiri la harus bekerja

* Tetapi juga mengabaikan rakyat di dunia, mereka tidak saja mengabaikan Saddam. 
Berdasarkan penjelasan di atas dapat dikatakan bahwa pelesapan subjek pada konstruski koordinatif dapat dilakukan bila subjek pada kedua klausa sama. Selain itu subjek yang dilesapkan berada pada klausa kedua atau setelah konjungtor koordinatif. Oleh karena unsur yang dilesapkan selalu berada setelah konjungtor koordinatif, acuan unsur yang dilesapkan selalu bersifat anaforis.

\section{b. Pelesapan Predikat dan Objek}

Pelesapan pada konstruksi koordinatif tidak hanya fungsi subjek, tetapi juga fungsi predikat dan objek seperti dibawah ini.

(11) Kami sudah menyerahkan semua persyaratannya, sedangkan dia belum $\varnothing$. (Kps, 27)

(12) Pemerintah akan mempermudah $\varnothing$ dan memperbaiki tata niaga kayu. $(\mathrm{KR}, 27)$

Pada kalimat (11) terjadi pelesapan klausa kedua. Predikat yang dilesapkan itu mengacu secara anaforis pada predikat klausa di depannya. Bila kalimat (11) ditulis lengkap menjadi (11). Kami sudah menyerahkan semua persyaratanya, sedangkan dia belum (menyerahkan semua persayaratannya). Gejala pelesapan predikat pada kalimat di atas sebenarnya sama dengan pelesapan subjek, yaitu pelesapan predikat hanya dapat dilakukan jika predikat pada kedua klausa tersebut sama dan predikat yang dilesapkan berada pada klausa kedua. Selain itu bila predikat yang dilesapkan diikuti oleh objek atau pelengkap dan kedua fungsi itu sama pada kedua klausa, objek dan pelengkap itu ada pada klausa pertama bukan pada klausa kedua atau klausa sesudah konjungsi. Sebaliknya bila objek atau pelengkap yang menyertai predikat berbeda pada kedua klausanya, perbedaan itu akan dimunculkan seperti pada kalimat beri- kut ini.

(13) Mereka membeli baju, sedangkan saya $\varnothing$ souvenir dari kulit kerang.

Pada kalimat itu terjadi pelesapan predikat membeli, tetapi karena objek dari predikat tersebut berbeda, objek tersebut tetap dimunculkan, tidak dilesapkan.

Berbeda dengan kalimat (11), kalimat (12) merupakan kalimat majemuk yang terdiri atas dua klausa. Pada klausa pertama atau klausa yang berada di depan konjungsi terdapat pelesapan unsur yang berfungsi sebagai objek. Unsur yang dilesapkan itu dapat dipulihkan berdasarkan teksnya, yaitu mengacu secara kataforis pada unsur objek yang ada pada klausa yang mengikutinya atau klausa yang berada sesudah konjungsi. Objek yang dilesapkan masing-masing tata niaga kayu. Dengan demikian bila ketiga kalimat tersebut ditulis lengkap akan diperoleh kalimat berikut ini.

(12a) Pemerintah akan mempermudah tata niaga kayu dan memperbaiki tata niaga kayu.

Berdasarkan kalimat tersebut tampak bahwa selain objek yang harus sama, posisi objek yang dapat dilesapkan adalah objek yang ada pada klausa pertama, bukan pada klausa kedua. Hal itu berbeda dengan kalimat (11) posisi objek yang dilesapkan ada pada klausa kedua, bukan pada klausa pertama. Hal itu dikarenakan objeknya mengikuti predikat. Bila predikat dilesapkan, secara otomatis objek juga dilesapkan (sekali lagi bila objek yang mengikuti predikat sama pada kedua klausanya). Dengan demikian bila pada kalimat (12b) objek yang dilesapkan ditempatkan pada posisi klausa sesudah konjungsi tidak berterima seperti tampak pada kalimat berikut ini. 
*(12b) Pemerintah akan mempermudah tata niaga kayu dan memperbaiki.

Berdasarkan penjelasan di atas dapat dikatakan bahwa pelesapan objek pada konstruksi koordiatif dapat dilakukan bila objek pada kedua klausa tersebut sama, dan objek yang dilesapkan harus berada pada klausa pertama atau klausa yang berada di depan konjungsi.

\section{Pelesapan dalam Konstruksi Sub- ordinatif}

Sebagaimana dikemukakan pada bagian hasil penelitian bahwa dalam konstruksi subordinatif hanya ditemukan pelesapan subjek, sedangkan pelesapan predikat dan objek tidak ditemukan. Pelesapan subjek dalam konstruksi subordinatif dalam dilihat pada kalimat berikut ini.

(14) Kalau 0 terlanjur busuk, ikan akan dibuang (Kps10)

(15) Jika 0 menang, Inggris akan menggungguli Turki dengan satu nilai. (KR, 31)

(16) Christian Vieri membuka peluang Italia ke putaran final setelah 0 memborong dua gol kemenangan tim (KR, 31)

Kalimat (14-16) merupakan kalimat majemuk tak setara atau suborditaif. Hal itu tampak dari jenis konjungtornya, yaitu kalau, jika, dan setelah. Klausa dalam kalimat tersebut memiliki hubungan yang tak sederajat atau tak setara. Pada ketiga kalimat tersebut terdapat unsur yang dilesapkan, yaitu unsur yang berfungsi sebagai subjek. Bila melihat ketiga kalimat di atas tampak bahwa unsurunsur yang dilesapkan pada kalimat (13-16) terdapat pada klausa terikat atau klausa yang berada sesudah konjungsi, sedangkan klausa yang tidak diawali dengan konjungsi fungsi sintak- sisnya lengkap, artinya tidak terdapat unsur yang dilesapkan. Namun, semua unsur yang dilesapkan dapat dipulihkan berdasarkan konteksnya. Pada kalimat (14-15) unsur yang dilesapkan mengacu secara kataforis pada klausa yang berada di belakangnya, yaitu ikan dan inggris Bila kedua kalimat tersebut ditulis lengkap akan didapat kalimat sebagai berikut:

(14a) Kalau (ikan) terlanjur busuk, ikan akan dibuang

(15a) Jika (Inggris) menang, Inggris akan menggungguli Turki dengan satu nilai

Berdasarkan arah acuan unsur yang dilesapkan kalimat (14-15) berbeda dengan kalimat (16) Pada kalimat (16) unsur yang dilesapkan mengacu secara anaforis pada anteseden yang ada pada klausa di depannya, yaitu unsur Christian Vieri. Dengan dasar itu bila ketiga kalimat tersebut dipulihkan akan didapat kalimat berikut ini.

(15a) Christian Vieri membuka peluang Italia ke putaran final setelah Christian Vieri memborong dua gol kemenangan tim.

Berdasarkan analisis, subjek yang dilesapkan selalu berada pada klausa terikat atau klausa yang berada sesudah konjungtor subordinatif. Tidak seperti dalam konstruksi koordinatif yang tidak dapat di balik posisinya, pada umumnya posisi klausa dalam konstruksi subordinatif dapat dibalik. Hal itu pula yang menyebabkan acuan unsur yang dilesapkan dapat kataforis dan anaforis. Pembalikan posisi itu pun tidak m e n gubah kegramatikalan kalimat. Bila kalimat (15) diubah posisinya akan didapat kalimat berikut.

(15a) Jika (Inggris) menang, Inggris akan menggungguli Turki dengan satu nilai. 
(15b) Inggris akan menggungguli Turki dengan satu nilai jika (Inggris) menang.

Implikasi dari pernyataan ini adalah bila subjek yang dilesapkan berada pada klausa bebas atau klausa yang tidak didahului konjungsi, pelesapan itu diragukan kebenarannya seperti data berikut ini.

(17) Jika mahasiswa mau bersabar, 0 tidak perlu main bakar di halaman kantor.(Kps, 28)

Pada kalimat (17) unsur yang dilesapkan ada pada kluasa bebas. Dengan posisi seperti itu klausa bebas tidak dapat berdiri di awal kalimat. Kedua kalimat tersebut tidak dapat diubah posisi klausanya seperti berikut ini.

$\left({ }^{*} 17\right.$ a) Tidak perlu main bakar di halaman kantor jika mahasiswa mau bersabar.

Selain tipe konstruksi kalimat yang seperti itu, kalimat yang subjeknya tidak sama tetapi dilesapkan juga tidak dapat dibenarkan, seperti pada kalimat berikut.

(18) Polisi mengerebek para tersangka ketika 0 sedang bermain sabung ayam.

Pada kalimat (18) fungsi subjek yang dilesapkan tidak mengacu secara anaforis pada subjek yanga ada pada klausa di depannya, yaitu polisi, tetapi mengacu secara anaforis pada objek yang berasa pada klausa di depannya, yaitu para tersangka. Dengan kata lain subjek pada kedua klausa tersebut berbeda. Hal itu tampak ketika kalimat itu dipulihkan menjadi Polisi mengerebek para tersangka ketika para tersangka sedang bermain sabung ayam. Oleh karena berbeda subjek maka pelesapan pada kalimat (17) tidak dibenarkan. Pelesapan pada kalimat (17) akan dibenarkan bila diubah menjadi Para tersangka digrebek polisi ketika sedang bermain sabung ayam. Dengan kalimat seperti itu subjek pada kedua klausanya sama sehingga salah satunya dapat dilesapkan.

Kalimat (17) berbeda dengan kalimat (18) yang merupakan data lisan. Hal yang perlu diperhatikan dalam data lisan adalah pelesapan subjek pada konstruksi subordinatif, tetapi tidak mengacu pada subjek dalam klausa bebasnya. Artinya subjek pada klausa bebas dan klausa terikat tidak sama, tetapi dilesapkan seperti tampak pada data berikut ini.

(19)Kalau mau dikembalikan ke fraksi, saya tidak bisa memahami. (Kps, 21)

Pada kalimat (19) jelas unsur yang dilesapkan tidak dapat dipulihkan berdasarkan konteksnya. Bila dipaksakan, yang terjadi adalah ketidaksesuaian makna antara kalimat asal dengan kalimat hasil pemulihan. Pelesapan itu hanya dapat dipulihkan berdasarkan situasi tutur. Dengan asusmsi bahwa yang dilesapkan sudah diketahui bersama antarpeserta komunikasi, selanjutnya unsur itu dilesapkan. Berdasarkan situasinya unsur yang dilesapkan adalah Rancangan UU. Dengan demikian kalimat itu secara lengkap akan tertulis Kalau rancangan UU mau dikembalikan ke fraksi, saya tidak bias memahami.

\section{E. Simpulan}

Berdasarkan analisis data di atas dapat disimpulkan beberapa hal berikut ini.

1. Kaidah pelesapan dalam konstruksi kalimat majemuk koordinatif adalah sebagai berikut.

a. Pelesapan subjek dapat dilakukan bila subjek pada kedua klausa yang digabungkan sama 
b. Subjek yang dilesapkan adalah subjek klausa yang berada sesudah kojungtor koordinatif.

c. Posisi klausa dalam konstruksi koordinatif tidak dapat dibalik. Oleh karena itu sifat acuan pelesapan subjek selalu anaforis.

d. Pelesapan predikat dapat dilakukan bila predikat pada kedua klausa yang digabungkan sama

e. Predikat yang dilesapkan adalah predikat klausa yang berada sesudah konjungtor koordintaif.

f. Bila ada objek yang mengikuti predikat dan objek tersebut sama pada kedua klausa, maka objek tersebut disebutkan pada klausa pertama atau klausa yang berada sebelum konjungtor.

g. Sifat acuan dari predikat yang dilesapkan adalah anaforis

h. Pelesapan objek dapat dilakukan bila objek pada dua klausa yang digabungkan sama

i. Objek yang dilesapkan adalah objek pada klausa pertama atau klausa yang berada sebelum konjungtor.

j. Sifat acuan objek yang dilesapkan adalah kataforis.

2. Kaidah pelesapan subjek daklam konstruksi kalimat majemuk subordinatif adalah sebagai berikut.

a. Pelesapan subjek dapat dilakukan bila subjek pada kedua klausa yang digabungkan sama.

b. Subjek yang dilesapkan adalah subjek klausa terikat atau klausa yang berada sesudah konjungtor.

c. Posisi klausa dalam konstruksi subordinatif dapat dibalik tanpa mengganggu kegramatikalan kalimat. d. Sifat acuan dari unsur yang dilesapkan kataforis dan anforis

\section{Daftar Pustaka}

Alwi, Hasan, Soenjono Dardjowidjojo, Hans Lapoliwa, dan Anton M. Moeliono. 1998. Tata Bahasa Baku Bahasa Indonesia. Jakarta: Balai Pustaka.

Alwi, Hasan. 1992. Modalitas dalam Bahasa Indonesia. Yogyakarta: Kanisius.

Brown, Keith dan Jim Miller. 1999. Concise Encyclopedia of Grammatical Categories. Oxford : Elsevier.

Kridalaksana, Harimurti. 1985. Tata Bahasa Deskriptif Bahasa Indonesia: Sintaksis. Jakarta: P3B.

Parera, Jos Daniel. 1991. Sintaksis. Jakarta: Gramedia.

Quirk, Randolph. Sidney Greenbaum, Geeofrey Leech dan Jan Starvik. 1985. A Comprehensive Grammar of The Englih Language. London: Longman.

Ramlan. M. 1987. Ilmu Bahasa Indonesia: Sintaksis. Yogyakarta: Karyono.

Shopen, Tymothy. 1996. Language Typology and Syntactic Description: Clause Structure. Cambridge: Cambridge University Press.

- 1996. Language Typology and Syntactic Description: Complex Constructions Cambridge: Cambridge University Press.

Sogono, Dendy 1985. Pelesapan Subjek dalam Bahasa Indonesia. Jakarta: P3B. 